The dimensions of the lamp are 4 inches $\times 3 \frac{1}{2}$ inches $\times 3 \frac{1}{2}$ inches. It consists of a small case containing an ordinary pocket lamp battery. Attached to the front of the case is an enclosed metal reflector, the aperture of which is covered with an opal glass. In front of the opal glass is a metal disc which contains a slit measuring $\frac{1}{2}$ inch $\times 2 \frac{1}{2}$ inches. When the electric current is turned on an evenly illuminated area the size of the slit is obtained. In a darkened room nothing is visible except the illuminated area, the lamp casting no light on surrounding objects.

The metal case of the lamp, in addition to the electric battery, contains a circular red glass for placing before the patient's eye, and also two strips of glass, one red, and the other white. The size of these strips is similar to the illuminated area of the lamp. The patient, during the examination, holds the two strips of glass, and is requested to place them in positions corresponding to the images that he sees.

The method has been tried on a number of patients with most satisfactory results. The patient is enabled to demonstrate to the surgeon the actual distance that he sees the images apart, and tilting of the images can be most accurately shown. The lamp is supplied by J. Fordham, Manufacturing Optician, Wallasey, Cheshire.

\title{
ANNOTATION
}

\section{The Education of Myopic Children}

We note with satisfaction that the report of the Council of British Ophthalmologists on the education of myopic children, which was published in the January number of this journal, has been commented upon favourably by a number of different periodical publications in various parts of the country.

The Morning Post was stimulated by it to send a representative to visit one of the myope schools in Islington, and to give its readers an account of the way in which the children's education is there carried out.

The Lancet not only published the report in full but also discussed it in an editorial annotation, advising that it should be studied by all educational authorities.

The Medical Officer, a journal for the medical men in the Government and municipal services, says : "It is not often that there comes to hand such a creditable report as that recently issued by the Council of British Ophthalmologists ; it is brief, it is balanced, 
it is written by men who are expert in their branch of medicine, and it concerns a most important subject." Its recommendations are, the journal says, very urgent, and it hopes "that this admirable report will be followed by the necessary action which would benefit so many sorely handicapped children."

The Glasgow Herald in its remarks says : "The chief difficulties in: the way of giving education to short-sighted children are the need for having the classes small in number, and the special training required for the teachers. These two facts taken together entail it is needless to say, a considerable financial outlay and the present is not a time when that can be lightly undertaken." The Lancet also comments on the extra expenditure which the Council's recommendations would entail, and the difficulties of the present time when the outcry in all Government Departments is for economy. Surely, however, it cannot be regarded as an economical policy for a State to carry on a form of compulsory education which tends to lower the standard of vision in its future workers, and in some instances produces inmates for its blind asylums.

\section{ABSTRACTS}

\section{I.-DISEASE OF THE UVEA}

(I) Fuchs, A.-On the propagation of sympathetic disease in the optic nerve. (Ueber die Fortleitung der sympathisierenden Entzündung in den Sehnerven.) Zeitschr. f. Augenheilk., Bd. LVI, H. 5-6, ss. 275-301, October., 1924.

(1) Fuchs has demonstrated histological lesions in the optic nerve in cases of sympathetic ophthalmitis, granulomatous in nature, which he considers specific to the disease, and which are of such a nature as to suggest that the method of propagation from one eye to the other is by direct spread of a virus along the nerve. He has studied in all 101 cases of sympathetic ophthalmitis; in 30 cases the optic nerve was not sectioned, in the remaining 71 it was examined histologically. Of these, in 17 the optic nerve and papilla were normal, although the characteristic epithelioid cell infiltration was present in varying degrees of intensity. In all the remaining 54 , there were changes in the nerve; in 24 there were definite lesions on the nerve trunk, especially marked in the pia, in 4 nodules of some size in the substance of the nerve. The favourite site of the lesion is the pia and its immediate vicinity, 